\title{
10. Political Liberalism and the Preventive Containment of Unreasonable Beliefs and Behavior
}

\author{
by Joonas Pennanen
}

\section{Introduction}

Etched into the self-understanding of most liberals, especially political liberals, is the notion of value being placed in toleration and political neutrality. We can agree to disagree if no unnecessary harm comes to others because of views held and professed. However, there is a wide array of beliefs and behavior such as hate speech, blatant racism, certain radical political views, and other practices like (illiberal) private education and certain, quite often religious, communal values that can be viewed as challenging to the liberal order and its values. These notions should be curbed, it is often argued, in order to protect the very fabric of a liberal society.

This paper examines the ways illiberal and/or unreasonable views can be contained legitimately in a political liberal society, and some of the pressing reasons to undertake, or abstain from, such measures. Theoretical background for the discussion is provided by Rawlsian political liberalism which quite often serves as a benchmark regarding the issue (§1). Although Rawls does not articulate a distinct conception of containment, his notion of political liberalism is especially interesting for the present purpose because of its anti-perfectionist character. Jonathan Quong, however, has presented a justification for the preventive containment of unreasonable views that is heavily influenced by Rawlsian political liberalism (\$2) and I intend to show that there are some quite significant worries concerning his particular take on the matter (§3). In the end, this paper puts forward a tentative suggestion that, in order to rise to the challenges presented, political liberals would do well to pay more attention to personal respect and relations of recognition $(\S 4)$.

No definitive solution to the problem of containment in political liberalism is provided here. Furthermore, the content of reasonableness is not examined, neither are more inclusive accounts of containment. The main purpose is to offer insight into the particular problems political liberals face when arguing for the preventive (and exclusive) containment of views. 


\section{§1 Background for Justifying Containment in Political Liberalism}

In Political Liberalism (2005/1993) John Rawls emphasized the need for normative stability based on the acceptance of a political conception of justice. That conception was found in a public culture of a liberal society and appealed to the use of public reason. The explicit aim was to establish grounds for the stable and just society given the fact of pluralism (Rawls, 2005, xviii-xix, 4). This invites the question of what measures are justifiable to guarantee the realization of such a society. ${ }^{1}$ In this section I discuss Rawls's remarks about containment and place his views among the common positions available regarding the topic. This provides a background for the examination of Jonathan Quong's alternative position in $\S 2$.

There are only a handful of paragraphs in which Rawls discusses the containment of potentially harmful, unreasonable political views using the specific term 'contain':

Of course, a society may also contain unreasonable and irrational, and even mad, comprehensive doctrines. In their case the problem is to contain them so that they do not undermine the unity and justice of society. (Rawls, 2005, xvi-xvii)

And:

That there are doctrines that reject one or more democratic freedoms is itself a permanent fact of life, or seems so. This gives us the practical task of containing them-like war and disease - so that they do not overturn political justice. (Rawls, 2005, 64 fn.19)

Rawls does not specify what he means by the term 'contain'. ${ }^{2}$ Although the distinction between reasonable and unreasonable is crucial in political liberalism, Rawls does not give much guidance about how liberals should engage with unreasonable people (Sleat, 2013, 357, 360; Gursozlu, 2014, 35). ${ }^{3}$ Nonetheless, academic discussion occupied with the topic is typically carried out in the framework of political liberalism. This testifies both to the fact of the theoretical significance of political liberalism and to its underlying logic of neutrality that, by restricting the range of viable state sanctions, accentuates the challenges involved in achieving stability.

In the literature covering the topic, three basic approaches to containment available to political liberals can be identified. The first is nonengagement ${ }^{4}$ in which voicing of illiberal ideas (or actions taken on such 
bases) is dismissed without arguing against those ideas. This is attributed to Rawls by Burton Dreben (2003) who maintains that Rawls does not need 'to argue against those who do not believe in constitutional democracy' since one does not argue for one's theoretical starting point. Instead, one should see where that leads to. Because certain conceptions of society are irrational and unreasonable, one should not spend time or energy in arguing against them (ibid., 323, 328). Clayton and Stevens (2014) assert that Rawls's position should not be construed to state that political liberals should say absolutely nothing to the unreasonable by way of justification for their dismissal. The key point is that no additional or extra justification should be given apart from the justifications 'for political obligations that are given in terms of political values which all reasonable citizens can in principle accept' (Clayton and Stevens, 2014, 73; also Quong, 2011, 312-4).

The second position available is that of the clear and imminent danger approach implying 'that it is permissible for liberal states to suppress the spread of illiberal doctrines and ideas only if they pose a clear and imminent danger to security and/or stability' (Ekeli, 2012, 172). Although Rawls does not discuss the issues relevant to containment at length, a position akin to the clear and imminent danger approach is quite often taken to be Rawls's 'orthodox' position regarding the containment of illiberal ideas and state coercion involved in the process (Nussbaum, 2011, 23; Quong, 2011; Ekeli, 2012). Indeed, although problems of subversive advocacy do not arise in the ideal circumstances of a well-ordered society, Rawls sees the right to free speech as violable only under very special circumstances of constitutional emergency (Rawls, 2005, esp. 346-8; 353-6). Kristian Ekeli asserts quite correctly that ' $t$ t]he liberal democratic state is not a suicide pact' (Ekeli, 2012, 185).

The approach allowing most latitude when it comes to coercive actions of the state is the preventive approach which allows certain measures to be taken to protect the liberal character of society even before there is a dire need for it. Indeed, it might be more than prudent to weed out the clearly unwanted tendencies before they prove to be a huge and possibly unsolvable problem for the liberal society and its liberal-minded citizens. ${ }^{5}$ Both the clear and imminent danger approach and the preventive approach try to calculate the level of threat to the liberal order. However, the former approach can be justified with a kind of foundational argument: in order to exist at all, the institutional framework of the liberal democratic society must be protected. Due to problems related to assessing the level, or even existence, of threat, that argument might be unavailable to proponents of the preventive approach.

From the perspective of Rawlsian political liberalism, most attempts 
to justify coercive actions undertaken by the state are quite problematic. The underlying premise and justification of political liberalism is its acceptability and/or justifiability that requires no perfectionist support (or support from comprehensive doctrines put forward as the goals of a political community) given to some set of values over others even if those values are liberal. In other words, the particular considerations related to the comprehensive wellbeing of a political community cannot, in principle, trump the dictates of the public reason and the political conception of justice giving content to it. ${ }^{6}$ This complicates the issue of justifying certain restrictions on basic liberties, e.g. free political speech, and Rawls doubted that there could be justifiable infringements of free political speech (in the name of comprehensive ethical values, or otherwise) even to protect the values of society that are undeniably liberal (cf. esp. Rawls, 2005, 355). On the other hand, persons and doctrines rejecting principles of liberal justice are to be contained, not compromised with (Freeman, 2007, 371), although the full import of the term 'contain' is more than vague in this context.

\section{$\S 2$ Quong's Conception of Preventive Containment}

Jonathan Quong has presented a new formulation of political liberalism in Liberalism Without Perfection (2011) that is given as a superior alternative to the perfectionist theories of liberalism. In this section, I offer a brief look at the underlying logic of Quong's particular way of justifying the use of preventive measures to contain the spreading and inculcating of unreasonable beliefs. ${ }^{7}$ The issues I consider problematic in his account are discussed in $\S 3$.

Quong follows the Rawlsian spirit quite closely in emphasizing the ideal character of his theory while offering an internal conception of political liberalism that aspires to formulate a general justification of liberal principles for people already committed to 'certain fundamental, but fairly abstract, liberal values' (ibid., 5-6). There are also quite a few notable differences between Rawls's and Quong's accounts, of which the most important for our discussion is Quong's argument

contra Rawls, that all our political decisions and deliberations should be governed by the idea of public reason. We should always want our political principles to be justifiable to others on terms those others can reasonably accept. We should not, as Rawls suggests, only apply this requirement to constitutional essentials and matters of basic justice. (ibid., 11) ${ }^{8}$ 
According to Quong, the 'primary intention [of containment] is to undermine or restrict the spread of ideas that reject the fundamental political values, that is, (a) that political society should be a fair system of social cooperation for mutual benefit, (b) that citizens are free and equal, and (c) the fact of reasonable pluralism' (ibid., 299). A justification for the containment can be grounded in 'the fundamental importance of normative stability in a well-ordered liberal society' (ibid., 300). Objectives that might threaten the stability of liberal regime (or, the basic rights of citizens) give the state a reason to 'permissibly restrict the actions of unreasonable citizens when it has a compelling moral reason to do so' (ibid., 11). Taken together we get a justification for containment that widens the scope of acceptability to preventive measures. Quong contends that the talk about unreasonable citizens might be misleading since 'it is not the unreasonable citizen who is excluded by public reason, but rather unreasonable views or claims' (Quong, 2011, 291). ${ }^{9}$ In that vein, the criteria for assessing the unreasonableness of citizens (or, their beliefs and behavior, see ibid.) can be presented as follows:

Unreasonable citizens reject at least one, but usually several of the following: (a) that political society should be a fair system of social cooperation for mutual benefit, (b) that citizens are free and equal, and (c) the fact of reasonable pluralism. Similarly, one qualifies as unreasonable if one accepts these ideals, but fails to accord them deliberative priority in one's practical reasoning. For reasonable people, these should be regulative ideas that generally limit one's beliefs about permissible actions or activities. (ibid., $291 ; 2012,74)$

Quong maintains that a person rejecting any of the three ideas above (or their deliberative priority) necessarily rejects 'the project of publicly justifying political power.' This denial of public justification indicates 'contempt for the fundamental moral ideal that underlies that project: the idea that citizens are free and equal, and as such, are entitled to justifications for the way political power is exercised over them.' Quong stresses the fact that 'the unreasonable' are still entitled to the general rights and benefits of citizenship just like more liberal-minded citizens, even if they are not part of the constituency determining those rights and benefits. The rights and benefits, and the limitations necessary to guarantee them, are still justifiable to the unreasonable although they do not actually give their consent ${ }^{10}$ (Quong, 2011, 291).

The notion of unreasonableness seems to play a particularly considerable justificatory role in Quong's account. With that notion defined, Quong has identified the type of conceptions that could be restricted but he still has to show the distinctiveness of containment from the regular application of liberal principles of justice (cf. §1: note 3). In order to justify 
preventive, restrictive measures one needs to offer a justification that goes beyond 'the usual,' general justification of political liberalism.

In deeming which right infringements are justified 'we should assess how real the threat is to the liberal democratic order' (ibid., 304). In the case of basic rights, a government is permitted to restrict the actions of unreasonable citizens only when supported by extremely compelling public reasons (ibid., 310-1). First, individuals or minorities who do not actively participate in the wider society-e.g. some religious communities like the Amish or other groups/movements advocating a highly reclusive life-styledo not pose a threat to the dominant order. Politically active but unreasonable citizens, on the other hand, 'clearly pose more of a stability threat, and so I think it is reasonable to suppose that the liberal state might need to apply a policy of containment more frequently to such groups' (ibid., 304.) Second, when discussing the case of education and the infringement of a right to educate/raise one's children as one sees fit, Quong notes that certain kinds of illiberal education might 'harm the children's capacity to develop and exercise one of their two moral powers: their capacity for justice' (ibid.). This moral power is 'the capacity to understand, to apply, and to act from the public conception of justice' (Rawls, 2005, 19). So, 'even if the threat to normative stability is relatively low, there may still be good grounds for intervention' (Quong, 2011, 305) ${ }^{11}$ I will name the first instance as the threat via political activity, in which the focus is on the communication and spreading of unreasonable ideas, and the second as the threat to self-realization, in which the inculcation of illiberal ideas impedes the formation of a moral and political identity in tune with the political conception of justice.

Quong presents 'another justification for limiting or restricting the behavior of unreasonable citizens' (Quong, 2011, 305) by asserting that 'there is no right to be unreasonable' (ibid., 309). ${ }^{12}$ Although 'unreasonable persons have all the normal rights and liberties of citizenship, it turns out these rights do not protect them in the pursuit of unreasonable objectives' (ibid.) rendering the rights claims of unreasonable citizens invalid (ibid., 291). Since 'all our political decisions and deliberations should be governed by the idea of public reason' (Quong, 2011, 11; also §2: fn.8) the class of potentially invalid actions is much wider than Rawls considered proper. Rawls also thought that the preventive restriction of certain views and rights might be illiberal and undemocratic as such. He contended that 'to restrict or suppress free political speech, including subversive advocacy, always implies at least a partial suspension of democracy.' The threat posed by political speech is 'of no particular moment' since 'political speech is by its nature often dangerous, or may often appear to be dangerous' (Rawls, 2005, 354).

Thus, the (otherwise valid) basic rights of the unreasonable can be 
infringed by preventively containing their views if those views 1) pose a threat (via political activity) to the liberal democratic order; 2) pose a threat to the self-realization of the capacity of justice; and 3) are promulgated/inculcated to pursue unreasonable objectives.

\section{$\S 3$ Worries}

In this section, I present some problems concerning Quong's justification of containment. ${ }^{13}$ The purpose is not to claim that political liberalism is the wrong way to approach the issue to begin with; instead the aim is to offer a couple of important considerations for the debate as a whole. It is, nonetheless, my intention to make a plausible case for why Quong's particular conception of containment should be revised, or at least complemented.

To begin with, Michele Bocchiola (2012) has noted that the criteria for assessing the seriousness of a particular threat might be too vague-it might often be almost impossible to ascertain whether the threat perceived is even real. On the other hand, to justify preventive measures and policies based on the fact that they deny liberal values 'might include unreasonable beliefs that do not properly form an unreasonable doctrine' (e.g. the beliefs might be based on quite harmless customs and conventions) rendering the criterion too broad ${ }^{14}$ (ibid., 46-48). For example, Martha Nussbaum has shown quite convincingly that 'there would appear to be many doctrines affirmed by reasonable citizens (in the ethical sense, respectful of one another) that do not meet ... rather exacting theoretical standards [of Rawlsian conception of reasonableness ${ }^{15}$ ]' (Nussbaum, 2011, 25). These include not only 'harmless customs and conventions' but major religions, which might very well accept the ethical content of political liberalism, as well (ibid., 25-30).

Cass Sunstein (2003) has highlighted the dangers that the exclusion of dissenting voices from the discussion and decision-making may bring about in general. In a free society, to exclude some beliefs from the public discussion is to do practically nothing about the fact that those same beliefs are still expressed and propagated in private circles (likely with even more vigor). This can lead to a group polarization through enclave deliberationthat is, people with quite moderate starting beliefs end up taking more extreme positions when deliberating only with the like-minded (ibid., esp. ch.6.). The preventive containment of unreasonable views might intensify threats to the liberal democratic order. Then again, the idea that certain unreasonable ideas should be contained because they harm individual selfrealization of proper moral capacity might miss its mark in assuming that to be in contact with illiberal views is a bad thing for the development of an 
individual's moral capacities. ${ }^{16}$ It is plausible that the worth of liberal values is recognized by citizens in active engagement with the unreasonable and their illiberal views. The actual contours of the reasonable disagreement would be clarified to all when argued against those opinions in public realm. The additional benefit would be that people holding unreasonable beliefs would not face a blunt rejection adjudged by the liberal majority even if the purpose of engagement would be the transformation of their beliefs.

James Bohman (2003) notes that toleration 'in the strong sense does not extend directly to the reasons as such but to the perspectives that inform these reasons and give them their cogency.' When these perspectives of others are recognized as legitimate, groups recognize themselves as contributing to common, democratic decision-making due to this inclusion of their particular perspectives (Bohman, 2003, 94-5.) Although 'respect is for persons, not for their doctrines ... these doctrines are deeply a part of people's search for the meaning of life' (Nussbaum, 2011, 22; cf. Quong, 2011, 291). Devaluation or denigration of those doctrines puts the holders of these doctrines at a disadvantage, 'suggesting that they are less worthy than other citizens, and, in effect, not treating them as fully equal end in themselves' (Nussbaum, 2011, 22; also McBride, 2013, 41). To insist on the correctness or the truth of one's own views is always a delicate matter, ever more so 'when it is government that sends the message [since] that changes the message, because government defines one's life-opportunities in a pervasive and fundamental way' (Nussbaum, 2011, 20, brackets added; also McBride, 2013, 25-6). With the stakes this high, it seems sensible to contain and restrict people's beliefs and behavior only in the cases of emergency. ${ }^{17}$

We can now turn to Quong's additional justification for the preventive containment, namely that there is no right to be unreasonable. He can be interpreted as presenting two somewhat different justifications for this claim. The first of these, the irrelevance account, is a controversial extension of the non-engagement approach while the second one, which I will call the lack of a right to pursue unreasonable objectives, focuses on conditions in which a right ceases to be a right. As far as I am aware, Quong himself has not differentiated these two arguments explicitly. ${ }^{18}$

According to the irrelevance account, unreasonable views (and accompanying arguments) 'are simply of no normative interest in the process of political justification' (Quong, 2004, 315). This falls within the nonengagement approach (cf. §1). No additional or extra justification should be given for one's theoretical starting point. However, the 'starting point' in question is not only theoretical, it is also moral. According to Quong, the denial of public, political justification indicates 'contempt for the fundamental moral ideal that underlies that project [of publicly justifying 
political power]' (Quong, 2011, 291). In the end, '[w]e coerce unreasonable citizens because to do otherwise would be to ignore what we must, as liberals, believe political justice demands' (ibid. 314). If the unreasonable views are of no normative interest when deciding the fairness/reasonableness of constitutional essentials (cf. Rawls) or the fairness/reasonableness of all our political decisions and deliberations (cf. Quong), does that justify containing and restricting these normatively irrelevant views?

Matt Sleat (2013) notes that the above is correct in a sense: when deciding how to cut a cake fairly one should disregard views of those wanting to keep the whole cake to themselves. What is unclear, however, is how this claim 'regarding the basis for excluding unreasonable persons from consideration in the justificatory process of the constitutional essentials can possibly explain or validate the legitimacy of coercing those same individuals to obey the principles which that process gives rise to'. The issue can be framed as a question of the relation between the justificatory constituency and the legitimacy constituency. The separation of the two constituencies represents 'a significant deviation from the standard liberal understanding of legitimacy'19 and means 'a drastic change in the function of legitimacy in liberal thought'. The separation of the two constituencies does not 'actually provide us with any grounds for thinking that the coercion of non-liberals is in any way consistent with their freedom, and hence not an act of oppression or domination. ${ }^{20}$ Even if this new understanding of liberal legitimacy is accepted, it mostly 'draws further attention to the fact that coercing such people is necessarily forcing them to live according to principles that they do not accept' (Sleat, 2013, 357-9).

The irrelevance account can perhaps be backed up with the idea of reasonable acceptance, the central claim of which is that constitutional essentials, policies, public deliberations etc. justifiable to all can be reasonably accepted. The liberal principle of legitimacy is thereby met without anyone actually giving their consent. However:

When normative constraint is imported ... it will turn out that all the important sorting work is done, not by the idea of reasons that all "can accept," but rather by the relevant normative notion, such as consistency with the requirements of reasonableness .... [The Rawlsian principle of legitimacy] effectively asks us to determine ... whether a given reason is consistent with the constitutive commitments of reasonableness, which are the same for each person. While one might stipulate that by a 'reason that all can accept' one means 
'a reason consistent with the constitutive requirements of reasonableness,' that would be a needlessly confusing terminological move. It would be franker to recognize that, on a normative approach such as Rawls's, the idea of what all could accept ... drops out. (Bohman and Richardson, 2009, 257, 260)

Although political liberals conceive the notion of acceptance in a particular way that differs from what many liberals are used to, perhaps the adjustment of thinking regarding the liberal conception of legitimacy is exactly what is needed. However, another worry emerges. Anthony Laden remarks that 'unequal relations of power generate the harm of misrecognition even if the powerful either positively or accurately identify the powerless .... [T] he imposition of an identity is a form of misrecognition even if the identity imposed would be endorsed by the powerless group' (Laden, 2007, 277). It is crucial to note that asking about 'how struggles for recognition will be taken up by the powerful is an institutional question' (ibid., 279). ${ }^{21}$ The identification of pathways by which these struggles 'can stake an undismissable claim to legitimacy' (ibid.) are central to the purpose of assessing the import of policies undertaken to ensure a certain hegemony of thought. According to Laden, the question of the responsiveness of political institutions to struggles for recognition becomes especially urgent when

the group struggling for recognition has achieved what I will call 'basic respect,' in the form of legal status, and even a measure of social esteem, but are nonetheless still denied what I will call 'fully equal respect'. That is, they fail to be recognized by those who maintain power over them as fully co-equal authors of the contours of their mutual relationship. ... [I]t is your understanding rather than mine that is effective in dictating the future course of the deliberation. In other words, it can happen if you have imposed an identity on me. Notice that this can happen even if we are both deliberating in good faith. (Laden, 2007, 270, 281)

The unreasonable or illiberal might become a group struggling for recognition on the grounds that they are denied a possibility to be co-equal authors of their mutual (political) relationship within a wider normative framework. ${ }^{22}$ The attempt to justify the containment with a sole reference to its justifiability might make one blind to certain deficiencies in the conception of reasonableness employed. There is always a good chance that, when we 
portray beliefs and behavior of some person or group as 'unreasonable, mere special pleading, or whining, ... what distorts our deliberation is an unequal distribution of constructive power' (Laden, 2007, 281). When some substantive considerations of personal freedom and political autonomy are sidestepped as irrelevant to the question of political legitimacy, the constructive power is utilized in a way that might be unjustified. More attention should be paid to the possible asymmetry in these kinds of social relations (of recognition). To do otherwise would run an additional risk of excluding the unreasonable outside the society in a way that they would be no longer disposed in any way to see the benefits of political liberal society. This renders the liberal project (of inclusion) virtually impossible.

What about the other alternative, which I have dubbed the lack of a right to pursue unreasonable objectives? Quong attempts to assess whether one has a right to be unreasonable, especially when faced with rights-conflicts. He surprisingly claims that Jeremy Waldron's (1993) account of rights, or the 'there is a right to do wrong' argument, supports the view 'that there is no such thing as the right to be unreasonable' (Quong, 2011, 307). Quong reminds us that ' $[\mathrm{r}]$ ights are only intended to permit or protect choices made within a limited domain' and they 'can only protect actions that respect the boundaries of other people's rights - once an act ceases to respect the rights of others, it is no longer possible for that act to be itself protected by a right' (ibid.). Indeed, sometimes we face situations where some rights must be restricted in order to protect others. But why are some right claims to be discarded? According to Quong, we need 'to ask whether the particular act that is alleged to be protected by a right is consistent with the overall moral ideal which the system of rights is meant to uphold' (ibid., 308). A little later, Quong goes on to state that

unreasonable activities are by definition inconsistent with the moral ideal upon which rights are grounded, and so they cannot be protected by such rights. Thus, although we have a right to do wrong, wrongness stands for something different than engaging in activities that are unreasonable. (ibid., 309)

This sounds rather vacuous. At the very least, it seems to be especially susceptible to worries regarding the reasonable acceptance and the use of constructive power presented before. The content of the normative constraints proposed is not the issue here, but the way those constraints are imposed. Nonetheless, according to Quong, a person can be prevented from exercising his rights 'when his aims are explicitly unreasonable-indeed they cease to be rights when he attempts to exercise them in this way' (Quong, 
2011, 310). Support for this position is drawn from Waldron, to whom the (free) speech of the Nazis is in its content and tendency incompatible with the very idea of the right they are asserting (Waldron, 1993, 223). Quong contends that the Nazis are not exercising a liberal right at all 'if we understand such rights to be grounded in the ideal of society as a fair system of social cooperation between free and equal citizens, each of whom are owed a reasonable justification for the exercise of political power' (Quong, 2011, 310).

Yet, the key difference between the cases of (the right to) educational choice and the Nazis' exercise of free speech 'rests on the fact that there are some reasonable interests being pursued by the parents in sending their children to the religious school, but the primary (and possibly only) interest being pursued in the Nazi case is unreasonable.' Therefore, there is a valid rights claim to be considered in the case of educational choice. Quong employs a notion of partial reasonability, the partiality of which is dependent on the consideration of whether the containment argument is 'strong enough to trump the pursuit of ... reasonable interests. ${ }^{23}$

'[T] hose activities the primary aims of which are unreasonable' fall into three categories: 1) 'those that threaten the rights of other citizens'; 2) instances in which, 'although they may not pose a plausible or immediate threat to the rights of other citizens, the argument for containment is applicable'; and 3) 'cases where the rights of other citizens are not threatened and where the containment argument does not properly apply.' Quong adds that the unreasonable groups 'that are also "partial citizens" or make no real effort to spread their views or obtain influence' would fall under the latter heading (Quong, 2011, 311.).

Thus, the unreasonableness of an aim is a key point along with the level of threat posed to the liberal society. This seems to go well with the emphasis on 'fundamental importance of normative stability' (ibid., 300). However, based on my examination, I have to conclude that Quong's account, in terms of justifying the preventive containment, does not bring that many new ideas to the table. Although he extends the notion of reasonability to all political deliberations and actions, therefore widening the scope of possible measures of containment considerably, the matter comes down to the assessment of sufficient (political) threat to the liberal order. In that regard, Quong provides no new grounds (for containment) in comparison to Rawlsian starting considerations. On the other hand, the way constructive power is used to justify the liberal order along with the use of coercive state power to limit activities whose primary aim is unreasonable stands in an uneasy relation with the ethical underpinnings and purposes of (political) liberalism. 


\section{$\S 4$ Conclusions}

I have examined the ways in which illiberal or unreasonable views can be contained legitimately in a political liberal society. I provided a background for the present discussion by going over three alternative ways of conduct with regard to containment-non-engagement, clear and imminent danger and preventive approaches - and discussed John Rawls's views in relation. After that, I presented Jonathan Quong's notion of preventive containment. In Quong's account, unreasonable beliefs and behavior are identified as the proper object of containment. More specifically they include actions and views that 1 ) pose a threat (via political activity) to the liberal democratic order; 2 ) pose a threat to the self-realization of the capacity of justice; and 3) are promulgated/inculcated to pursue unreasonable objectives. The bulk of the paper was reserved to present worries that political liberals should take into account when justifying containment of certain illiberal views. Since Quong explicitly extends the dictates of reasonableness from the basic structure of society to all political decisions and deliberations, it is especially pertinent to provide strong reasoning to justify such containment. Unfortunately, Quong's account was found to not answer the concerns identified adequately. Some of these issues can be seen to follow directly from the way political liberals justify their views in general, and they should not perhaps be seen as deficiencies in either argumentation nor ethical underpinnings, in general or in Quong's particular case. However, they underline the need to revise or complement the justification for the containment of illiberal views.

Most of the worries presented in this paper point towards paying more attention to relations of recognition, and for the need for a stronger conception of respect towards persons instead of abstract justifiability. The concerns identified here allude to why one might want to argue for a more inclusive approach in respect to the issue of containment. To produce such an account is, however, a matter for another paper. ${ }^{24}$

Joonas Pennanen (joonas.h.s.pennanen@student.jyu.fi) is a PhD student at University of Jyväskylä. He is writing his doctoral dissertation on W.B. Gallie's essentially contested concepts and the nature of endless, intractable disagreements. 


\section{Bibliography}

Bocchiola, M. (2012) 'Liberalism, Containment, and Education' Philosophy and Public Issues 2 (2), pp. 43-50

Bohman, J. (2003) 'Reflexive Public Deliberation: Democracy and the Limits of Pluralism’ Philosophy \& Social Criticism 29 (1), pp. 85-105

Clayton, M. \& Stevens, D. (2014) 'When God Commands Disobedience: Political Liberalism and Unreasonable Religions' Res Publica 20, pp. 65-84

Dreben, B. (2003) 'On Rawls and Political Liberalism' in S. Freeman (ed.) The Cambridge Companion to Rawls Cambridge: Cambridge University Press, pp. 316-46

Ekeli, K. (2012) 'Liberalism and Permissible Suppression of Illiberal Ideas' Inquiry: An Interdisciplinary Journal of Philosophy 55 (2), pp. 171-93

Freeman, S. (2007) Rawls New York: Routledge

Friedman, M. (2000) 'John Rawls and the Political Coercion of Unreasonable People' in V. Davion \& C. Wolf (eds) The Idea of a Political Liberalism: Essays on Rawls Rowman \& Littlefield, pp. 16-33

Gursozlu, F. (2014) 'Political Liberalism and the Fate of Unreasonable People' Touro Law Review 30 (1), pp. 35-56

Kelly, E. \& McPherson, L. (2001) ‘On Tolerating the Unreasonable' Journal of Political Philosophy 9, pp. 38-55

Laden, A. (2007) 'Reasonable Deliberation, Constructive Power, and the Struggle for Recognition' in B. van den Brink \& D. Owen (eds.) Recognition and Power: Axel Honneth and the Tradition of Critical Social Theory Cambridge: Cambridge University Press, pp. 270-89

Larmore, C. (1999) 'The Moral Basis of Political Liberalism' Journal of Philosophy 96, pp. 599-625

Larmore, C. (2003) 'Public Reason' in S. Freeman (ed.) The Cambridge companion to Rawls Cambridge: Cambridge University Press, pp. 368-93 
McBride, C. (2013) Recognition Cambridge and Malden: Polity Press

Nussbaum, M. (2011) 'Perfectionist Liberalism and Political Liberalism' Philosophy \& Public Affairs 39 (1), pp. 3-45

Quong, J. (2004) ‘The Rights of Unreasonable Citizens' The Journal of Political Philosophy 12 (3), pp. 314-335

Quong, J. (2011) Liberalism Without Perfection Oxford: Oxford University Press Quong, J. (2012) 'Liberalism Without Perfection: Replies to Gaus, Colburn, Chan, and Bocchiola' Philosophy and Public Issues (New Series) 2 (1), pp. 5179

Rawls, J. (1999/1971) A Theory of Justice: Revised Edition Cambridge (Mass.): Belknap Press of Harvard University Press

Rawls, J. (1985) 'Justice as Fairness: Political not Metaphysical' Philosophy E Public Affairs 14 (3), pp. 223-251

Rawls, J. (2005/1993) Political Liberalism: expanded edition New York: Columbia University Press

Rawls, J. (2001) Justice as Fairness: A Restatement (ed. Kelly, E.) Cambridge, Mass.: Belknap Press of Harvard University Press

Sleat, M. (2013) 'Coercing Non-Liberal Persons: Considerations on a More Realistic Liberalism' in European Journal of Political Theory 12 (4), pp. 347-67

Stemplowska, Z. \& Swift, A. (2014) 'Rawls on Ideal and Nonideal Theory' in J. Mandle \& D. A. Reidy (eds.) A Companion to Rawls Chichester: John Wiley Sons, Inc., pp. 126-41

Sunstein, C. (2003) Why Societies Need Dissent Cambridge, Mass.: Harvard University Press

Waldron, J. (1993) Liberal Rights: Collected papers 1981-1991 Cambridge: Cambridge University Press 


\section{Endnotes}

1 When Political Liberalism is read separately from a Theory of Justice (1999/1971) the key questions become 'the practical possibility of a wellordered liberal society,' and 'the conditions of the legitimacy of the exercise of political power in a liberal society' (Freeman, 2007, 324).

2 To mean something distinctive, Jonathan Quong contends, the idea of containment has to be 'defined in a way that does not simply collapse into the protection of basic individual rights and freedoms' (Quong, 2011, 299) i.e. it is not just regular application of liberal principles of justice. 'The aim, in other words, has to be containment of a doctrine rather than protection of basic rights, even if the action may produce both consequences' (ibid.)

${ }^{3}$ For a summary of Rawls's remarks, especially concerning the notion of unreasonableness in the present context, see Gursozlu, 2014, 35-41.

${ }^{4}$ For Rawls's closest use of the term, see 2005, 442.

${ }^{5}$ There are quite a few problematic issues involved with the preventive approach, some of which are discussed in more detail in $\S 3$. For the view that the preventive approach is justified under a certain guiding set of principles, see e.g. Ekeli, 2012.

6 '[C]ontinuing shared understanding on one comprehensive religious, philosophical, or moral doctrine can be maintained only by the oppressive use of state power ... Call this "the fact of oppression" .... We may mistakenly think there are exceptions for other [reasonable] comprehensive views .... [T] here are no exceptions' (Rawls, 2005, 37; 37,fn.39).

${ }^{7}$ Quong has presented this argument already in the article 'The Rights of Unreasonable Citizens' (Quong, 2004). In Chapter 4 of Liberalism Without Perfection (2011), he also advocates a duty-based conception of legitimate authority - which I do not discuss here-according to which 'the liberal state can legitimately exercise political power over citizens provided that accepting the state's commands is likely to be the best way to achieve what justice requires' (ibid., 313).

${ }^{8}$ Consider the following: 'Views that are unreasonable are not simply nonpublic doctrines: they have an inescapably political element because they 
reject the central political values of liberal democracy. If this is true, then the state has good reasons to worry about the spread of unreasonable beliefs, even in non-public arenas such as religious expression' (Quong, 2011, 303; but cf. 296). It seems that Quong is at least somewhat willing to blur the demarcation line important to most liberals, namely the one between public and private, when it comes to the coercive use of state power. Of course, that line is, in fact, blurred in actual, non-ideal societies but whether it should be blurred when treating the matter 'at the level of principle' (ibid., 305) is another matter.

${ }^{9}$ Quong refers to the unreasonable (citizens) 'for simplicity and ease of exposition' (Quong, 2011, 291).

10 The objections against Rawlsian position presented by Marilyn Friedman (2000) and Erin Kelly and Lionel McPherson (2001) are rejected by Quong who thinks their critiques rely on the false assumption that those who are not part of the justificatory constituency, or 'legitimation pool' (Friedman, 2000, 16, 29), are deprived of their basic rights. Fuat Gursozlu criticizes both Friedman's and Quong's positions of being solely preoccupied with the question of rights (Gursozlu, 2014, 50; cf. Rawls, 1999, 190-4). Instead, 'one should shift the focus ... to the educative [transformative] effects of political liberalism on unreasonable citizens' (Gursozlu, 2014, 36).

${ }^{11}$ For Rawls's brief remarks regarding the education of children in this context, see Rawls, 2001, 156-7.

${ }^{12}$ Quong builds upon Jeremy Waldron's notion of the right to do wrong (1993) by asserting that once we make a (sensible) distinction between wrongness and unreasonableness, Waldron's account of rights supports his position (Quong, 2011, 307). The matter is further discussed in $\S 3$.

${ }^{13}$ For various critiques of and/or doubts about Quong, see Bocchiola, 2012 (for reply, see Quong, 2012); Ekeli 2012; Gursozlu, 2014.

14 To require the fulfillment of both criteria might leave out too much.

${ }^{15}$ Nussbaum's comments presented in this paper are offered in critique of Rawls (esp. Rawls, 2005, 36, 55).

${ }^{16}$ According to Rawls, the observance of a stark conflict seems to be the very 
thing needed for political liberal consciousness to emerge at all in the course of history (Rawls, 2005, xxiv-xxvi; Rawls, 1985, 249).

${ }^{17} \mathrm{Cf}$. the clear and imminent danger approach in $\S 1$. Note that Rawls is, by no means, unaware of the importance of self-respect which he has described as 'the most important primary good' (see esp. Rawls, 1999, §67, 477).

18 The term 'irrelevance' is used by Matt Sleat who argues that Quong has 'fleshed out this position in a compelling way' (Sleat, 2013, 357). I am not that certain that Quong would subscribe to it (as a justification for containment) explicitly although it indeed seems that he is advocating it effectively. See also §3: note 22 .

${ }^{19}$ Regarding the liberal understanding of legitimacy referred to; see Sleat, 2013, 349-52 and Larmore, 1999, 607-8. Kristian Ekeli also expresses a doubt that Quong's conception might not respect the autonomy of persons (Ekeli, 2012, 187 and fn.9).

${ }^{20}$ In contrast to this particular way of justifying the containment, recall also §1: note 6 .

${ }^{21}$ Regarding institutions in this context, see also McBride, 2013, 83, 129-30, 141, 158.

${ }^{22}$ One way to characterize the situation is that they have certain normative expectations that fail (McBride, 2013, 150-1).

${ }^{23}$ This marks a notable difference to Rawls. Consider $§ 1$ : note 6 which seems to state the opposite to: '[the fundamental ideal of society as a fair system of social cooperation between free and equal citizen] is where our reasoning about justice begins, it does mean that the rights and benefits of citizenship are meant to aid citizens only in the pursuit of those conceptions of the good life that are compatible with that ideal' (Quong, 2011, 312).

24 I am grateful to Arto Laitinen and the other project-members of "Pathologies of Recognition" for their comments on earlier drafts of this article. I also express my sincere thanks to Alison Beale for proof-reading the final draft. 